\title{
Penile Lymphangioma
}

National Cancer Institute

\section{Source}

National Cancer Institute. Penile Lymphangioma. NCI Thesaurus. Code C162592.

A lymphangioma that occurs in the skin of the penis. 